\title{
Effect of Kombucha Tea on Total Cholesterol Decreasing Levels in White Rats (Rattus norvegicus)
}

\author{
Zulkifli Halid $^{1 *}$, Sulaiman ${ }^{1}$, Rifka Irhamna ${ }^{2}$ \\ ${ }^{1}$ Department of Pharmacy, Faculty of Medical and Health Science, Universitas Muhammadiyah Makassar \\ Sultan Alauddin Street No. 259, Rappocini, Makassar, South of Sulawesi \\ 2 Department of Pharmacy, Faculty of Pharmacy, Universitas Indonesia Timur, \\ Rappocini Raya Street No. 171-173, Rappocini, Makassar, South of Sulawesi \\ *Corresponding author e-mail: zulkiflifkik@unismuh.ac.id
}

\begin{abstract}
The purpose of this study was to determine the type of content of $75 \%$ kombucha tea that is fermented for 12 days, there are black tea, green tea, and the packaged tea. Fifteen Rattus norvegicus was randomized divided into 5 groups and each group consisted of 3 rats. Group I or the negative control was given aquadest, group II was given kombucha packaged tea, group III was given black tea kombucha, and group IV was given green tea kombucha. Group $V$ as a positive control was given simvastatin. All groups were injected with the samples solution orally. Evaluation of effects was carried out by observed the cholesterol total level before and after treatment. The results showed that all kombucha tea can reduced the total cholesterol level on rats (Rattus norvegicus). Conclusion: Data were analyzed using ANOVA followed by Duncan test with 95\% confidence level using SPSS 20.0 software, results showed that black tea kombucha $1.8 \mathrm{~mL}$ of $75 \%$ concentration has an optimal reduced total cholesterol levels in rats (Rattus norvegicus).
\end{abstract}

KEYWORDS: Rattus norvegicus, kombucha tea, Total Cholesterol

\section{INTRODUCTION}

Tea has long been known as a drink with distinctive taste and health benefits. The culture of drinking tea originated in China since $2737 \mathrm{BC}$, to be precise during the time of the emperor Shen Nung Kam (Alamsyah, 2006). Kombucha tea is a fermentation tea that plays a role in fat metabolism so that it has the potential to reduce levels of LDL (Low Density Lipoprotein), and triglycerides, and increase HDL (High Density Lipoprotein) levels (Henry, 2008). Hyperlipidemia is mainly caused by the intake of foods high in fat content which can cause atherosclerosis, which can lead to coronary heart disease and stroke (Fajrin, Fifteen Aprila, 2010).

Research that discusses kombucha tea has been widely reported. The activity of SCOBY (Symbiotic Culture of Bacteria and Yeast) causes increased antioxidant activity in kombucha after fermentation. In addition, there was also an increase in phenolic and acidic in kombucha drink (Azrini Khaerah, Fauzan Akbar, 2019). Kombucha tea can provide hepatoprotective effects through antioxidant activity and mitochondrial pathways. Oxidants are modulated from glucuronic acid which is a fermented product of kombucha tea. (Yuliana, 2014). The type of tea is very influential on the antioxidant 
capacity, total acid, and the analysis of the best kombucha is the one made from white tea with the characteristic antioxidant capacity of 807.76 ppm. (Ketut Ita Purnama, et all, 2018). The antioxidant activity has an optimal value on the 7th day of fermentation of $93.79 \%$ and continues to decrease with the length of fermentation. The yeast used in the fermentation process is Saccharomyces cereviceae which will oxidize alcohol to acetic acid. (Maulina Nurikasari, et all, 2017)

Based on the above background, the problem that arises from this study is what type of kombucha tea is the most optimal in reducing total cholesterol levels in white rats (Rattus norvegicus).

\section{MATERIAL AND METHODS}

\section{Chemicals and Instrument}

The instrument used are stirring rod, glass bottle, measuring cup, beaker glass, stainless pan, gauze, rubber band, digital scale, glucometer, oral spoit, rubber band, soft cloth, $5 \mathrm{ml}$ spoit.

The chemical used are Aquades, sugar, green tea, black tea, packaged tea, kombucha starter (scoby), Simvastatin $20 \quad \mathrm{mg}$, Propylthiouracil $100 \mathrm{mg}$, filter paper, gauze, high cholesterol feed, white rat (Rattus norvegicus), $\mathrm{Na} \mathrm{CMC} 1 \% \mathrm{w} / \mathrm{v}$.

\section{Sampling and Processing of Samples}

The sample were green tea, black tea and packaged tea obtained in the Makassar area and kombucha yeast in the Java area, then the samples were processed and fermented.

\section{Fermentation of Kombucha Tea}

Aquadest cooked as much as $800 \mathrm{ml}$ in a stainless pan until it boils. Put 150 grams into a pan, cook until the volume reaches $200 \mathrm{ml}$. The solustion then filtered and added 20 grams of sugar and stirred until the sugar is completely dissolved. The solution reaches to room temperature and then is transferred into a beaker glass. The kombucha starter and kombucha yeast added in a beaker glass. The beaker is closed with a cloth and fermented for 12 days in protected from direct sunlight place.

\section{Making Na CMC 1\%}

$\mathrm{Na} \mathrm{CMC}$ is weighed 1 gram. Then put into $50 \mathrm{ml}$ of distilled water which has been heated at $70^{\circ} \mathrm{C}$ of temperature. The suspension is stirred until homogeneous, and the volume is made up with distilled water up to $100 \mathrm{ml}$. The suspension is then stored in the container provided.

\section{Treatment of Test Animals}

White rats (Rattus norvegicus) were fasted for about 8 hours and weighed the initial weight. White rats were divided into 5 groups, the initial cholesterol level was measured using a glucometer, then given a solution of propylthiouracil and a highcholesterol diet as a cholesterol inducer. After 7 days the rats were given propyltiouracil suspension and high-fat food, then the total cholesterol levels were measured again in 
Table 2. White Rats Total Cholesterol Level Before and After Treatment with Kombucha Tea $75 \%$.

\begin{tabular}{lcccc}
\hline \multicolumn{1}{c}{ Treatment } & $\begin{array}{c}\text { Initial } \\
\text { Cholesterol }\end{array}$ & $\begin{array}{c}\text { Cholesterol } \\
\text { Induction }\end{array}$ & $\begin{array}{c}\text { Cholesterol after } \\
\text { treatment }\end{array}$ & \%Reduction \\
\hline Negative Control & $173,67+14.98$ & $242.00+8.54$ & $230.67+6.03$ & $16 \%$ \\
\hline Packaged Tea & $186.67+10.50$ & $251.33+10.69$ & $220.00+12.77$ & $51 \%$ \\
\hline Black Tea Kombucha & $180.67+5.03$ & $258.67+4.73$ & $187.33+10.59$ & $92 \%$ \\
\hline Green Tea Kombucha & $178.00+12.12$ & $238.33+5.69$ & $195.00+5.19$ & $78 \%$ \\
\hline Positive Control & $161.00+14.42$ & $255.00+13.00$ & $173.00+12.17$ & $88 \%$ \\
\hline
\end{tabular}

white rats, to see if their cholesterol levels had risen. After the cholesterol in white rats rised, then the treatment group II, III, IV were given packaged tea, Black tea kombucha, and green tea kombucha respectively.and Group I as a negative control who was only given Aquadest orally, and group $\mathrm{V}$ as a comparison group (positive control), was given a $20 \mathrm{mg}$ suspension of simvastatin. All groups were carried out for 3 replications. Total cholesterol levels were measured in white rats initial $\left([C]_{0}\right)$, before $\left([C]_{\text {ind }}\right)$ and after $\left([C]_{\text {tre }}\right)$ treatment using glucometer. Reduction percentage (\% reduction) was calculated by

$\%$ reduction $=\frac{C_{\text {ind }}-C_{\text {tre }}}{C_{\text {ind }}-C_{o}} x 100$.

Data analysis with ANOVA using the SPSS program.

\section{RESULTS AND DISCUSSION}

Based on the research that has been done, kombucha tea with concentration of $75 \%$ with fermentation for 12 days can reduce the total cholesterol of white rats in test animals. The concentration of $75 \%$ with fermentation for 12 days shows the glucuronic acid reached its maximum value after 12 days. All types of kombucha tea reduce cholesterol levels in white rats. For the maximum effect that can reduce the total cholesterol level of the tested animals is a type of black tea with a decrease in total cholesterol levels by $92 \%$, when compared with positive control (simvastatin) which is only $88 \%$. The effect of lowering total cholesterol levels comes from the antioxidants in kombucha drinks after fermentation. The ANOVA analysis illustrate that there is a significance effect of kombucha tea treatment on decreasing cholesterol levels $(0.000<0.05)$. In addition, there was also an increase in total phenolic and total acidic in the kombucha drink The black kombucha tea has a maximum level of glucuronic acid on fermentantion as antioxidant activity then other tea (Azrini Khaerah, Fauzan Akbar, 2019).

\section{CONCLUSION}

This study indicated that all types of kombucha tea with a level of $75 \%$ fermentation for 12 days can reduce total cholesterol levels in white rats (Rattus norvegicus), and the most effective in reducing total cholesterol levels in white rats (Rattus norvegicus) is black kombucha tea with a reduction rate of up to $92 \%$. 


\section{REFERENCES}

Alamsyah. (2006). Taklukkan Penyakit dengan Teh Hijau . Jakarta: Agromedia Pustaka.

Azrini Khaerah, Fauzan Akbar. (2019). Aktivitas Antioksidan Teh Kombucha dari Beberapa Varian Teh yang Berbeda. Prosiding Seminar Nasional LP2M UNM, 472-476.

Fajrin, Fifteen Aprila. (2010). Aktivitas Ekstrak Etanol Ketan Hitam Untuk Menurunkan Kadar Kolesterol. Jurnal farmasi Indonesia, 63-69.
Henry, N. (2008). Kombucha Teh Dengan Seribu Khasiat. Jakarta: Agromedia Pustaka.

Ketut Ita Purnama, et all. (2018). Pengaruh Jenis Teh Terhadap Karakteristik Teh Kombucha. ITEPA, 7(2), 1-10.

Maulina Nurikasari, et all. (2017). Characterization And Analysis Kombucha Tea Antioxidant. Journal of Global Research in Public Health, 2(2), 90-96.

Yuliana. (2014). Hepatoprotective Property of Kombucha Tea. Jurnal Ilmiah Kedokteran, 99-102. 